\section{ADMINITRASI KURIKULUM}

\author{
Nola nopita \\ Universitas Negeri Padang \\ Indonesia \\ E-mail : \\ nollanopita@gmail.com
}

\section{Abstract}

Administration is an effort to create cooperation between teachers and employees to streamline the teaching and learning process. The purpose of this article is to provide knowledge about educational administration in the field of teacher training. Educational administration is also all the techniques and procedures used in implementing educational relations in accordance with established policies in order to achieve educational goals. In order to operationalize the concept of education administration. Schools as educational organizations must manage three things, namely material, human resources, and curriculum

\section{A. Pendahuluan}

Indonesia, pendidikannya berjalan secara pesat pada abad ke 20. Tidak dapat dipungkiri, bahwa sepanjang sejarah perjalanan bangsaIndonesia sering kali dilakukan perubahan/penggantian kurikulum. Permasalahan pendidikan yang sering menjadi perhatian adalah masalah $\underline{\text { kurikulum dan administrasi pendidikan. }}$

Konsep kurikulum berkembang sejalan dengan perkembangan teori dan praktik pendidikan, juga bervariasi sesuai dengan aliran atau teori pendidikan yang dianut oleh pakarnya. Perubahan dan pengembangan kurikulum dianggap sebagai salah satu titik krusial di dalam penanganan masalahmasalah pendidikan, khususnya pendidikan formal. Dalam kurikulum terintegrasi filsafat, nilai- nilai pengetahuan, dan perbuatan pendidikan. Kurikulum disusun oleh para ahli pendidikan/ahli kurikulum, ahli bidang ilmu, pendidik, pejabat pendidikan, pengusaha serta unsur- unsur masyarakat lainnya. Rancangan ini dimaksudkan memberi pedoman kepada pelaksana pendidikan, dalam proses pembimbingan perkembangan siswa, untuk mencapai tujuan yang dicita-citakan oleh siswa sendiri, sekolah, keluarga, maupun masyarakat. Sedangkan administrasi kurikulum perlu dan penting dalam penyelenggaraan dan pengembangan pendidikan, agar tujuan pendidikan yang telah dirumuskan dapat di dayagunakan secara efektif dan efisien.

\section{B. PROSES ADMINISTRASI}

\section{KURIKULUM}

Ada beberapa proses administrasi kurikulum sebagai berikut :

\section{Perencanaan Kurikulum}

Di dalam perencanaan kurikulum terdapat sekitar masalah tanggung jawab untuk menentukan: Harus bagaimana bentuk kurikulum itu. Siapa yang merencanakan dan bilamana. Ada yang mengemukakan pendapat bahwa perencanaan kurikulum adalah pekerjaan yang memerlukan keahlian 
dan karena itu dikerjakan oleh para ahli atau "expert" dalam bidang perencanaan kurikulum. Menurut pendapat ini kurikulum harus direncanakan baik-baik sebelumnya. seringkali secara terperinci mengenai situasi belajar, dan semua murid di semua sekolah tingkat tertentu mempunyai kurikulum yang kira-kira seragam, Mengenai perencanaan dimuka atau "Pre-Planning" terdapat perbedaan pendapat dalam hal sejauh mana perencanaan dimuka dapat dilakukan. Ada beberapa ahli yang mengemukakan pendiriannya, bahwa tidak ada aspek-aspek kurikulum yang harus direncana jauh sebelum situasi belajar berlangsung. Untuk penjelasan singkat, pendapat-pendapat yang berbeda itu dapat dikelompokkan sebagai berikut:

a. Kurikulum seharusnya direncanakan di muka secara terperinci oleh "experts" dalam bentuk kumpulan mata pelajaran.

b. Kurikulum direncanakan secara terperinci di muka oleh panitia yang terdiri dari guru-guru dalam bentuk kumpulan mata pelajaran.

c. Kurikulum direncanakan dalam garis besarnya yang luas oleh panitia yang terdiri dari guru-guru dalam bentuk pedoman kerja. perincian dilakukan oleh guru berdasarkan kebutuhan-kebutuhan murid. d. Kurikulum direncanakan dalam garis besarnya berisi partisipasi dari guru-guru dan tokoh-tokoh masyarakat. perincian dilakukan oleh perencanaan bersama guru murid.

e. Kurikulum direncanakan oleh guru bersama murid pada waktu akan belajar, tanpa perencanaan jauh dimuka.

\section{Pelaksanaan Kurikulum}

Sebelum kurikulum benar-benar dilaksanakan, harus terlebih dahulu memperhatikan perbedaan-perbedaan individual. Yang dimaksud disini adalah masalah penyesuaian program pengajaran terhadap perbedaan-perbedaan di antara anak-anak. Jawaban terhadap persoalan ini macam-macam. Kurikulum yangn berorientasikan kumpulan mata pelajaran berasal dari zaman sebelum ada pengetahuan tentang perbedaan-pebedaan individu dan kemapuan pada murid. Pada waktu itu orang menganggap semua murid (kecuali anak-anak lemah jiwa) dapat menguasai semua mata pelajaran yang diberikan disekolah dengan kepandaian yang sama asal mereka rajin belajar.

Pada umumnya diakui bahwa makhluk manusia sangat beraneka ragam dalam kemampuannya untuk maju. Keadaan itu telah menggerakkan para pendidikan kepada perbedaan-perbedaan individual ini. Disini 
timbul perbedaan-perbedaan pendapat mengenai persoalan bagaimana hal ini harus dilaksanakan.

1) konsep kurikulum yang telah di tetapkan jauh di muka harus dikuasai oleh semua murid menurut kecepatan yang telah diatur sebelumnya. Masalahnya ialah menyesuaikan individu-individu yang mempunyai kecepatan belajar yang berbedabeda pada "realitas" ini.

2) bahwa murid-murid harus dikelompokkan menurut kemampuannya dengan tujuan bahwa pengelompokan ini akan memperkecil perbedaan kemampuan dalam tiap kelompok agar mempermudah pelaksanaan individualis program pengajaran.

3) menciptakan jenis kurikulum berdasarkan pengalaman yang dipusatkan kepada masalah-masalah dan memberikan kesempatan kepada kelompok-kelompok tesebut dalam pendapat kedua untuk bekerja sama memecahkan masalah bersama, yang menarik perhatian bersama. Hal ini menunjukkan tiap anggota kelompok untuk mampu bekerja menurut taraf perkembangan masing-masing dalam bidang akademis sosial dan emosi dan masih menunjang usaha bersama kelompok.
3. Pengawasaan / Pengembangan Kurikulum

Dalam Pengembangan Kurikulum terdapat dua proses utama, yakni Pengembangan Pedoman Kurikulum dan Pengembangan Pedoman Instruksional.

a. Pedoman Kurikuklum, meliputi:

$\varnothing$ Latar belakang yang berisi rumusan Falsafah dan tujuan lembaga pendidikan, populasi yang menjadi sasaran, rasional bidang studi atau mata kuliah, struktur organisasi bahan pelajaran.

$\varnothing$ Silabus yang berisi mata pelajaran secara lebih terinci yang diberikan yakni Scope (ruang lingkup) dan Sequence-nya (urutan pengajiannya).

$\varnothing$ Desain evaluasi termasuk strategis revisi atau perbaikan kurikulum mengenai: Bahan pelajaran (Scope dan Sequence) Organisasi bahan dan strategi intruksionalnya

b. pedoman instruksional

Pedoman Instruksional diperoleh atas usaha pengajar untuk menguraikan isi pedoman kurikulum agar lebis spesifik sehingga lebih mudah untuk mempersiapkannya sebagai pelajaran dalam kelas. dengan demikian apa yang diajarkan benar-benar bersumber dari pedoman kurikulum.

4. Evaluasi Kurikulum

a. Dasar-dasar Evaluasi Kurikulum

Evaluasi kurikulum bermacam-macam tujuannya, yang paling penting di antaranya ialah: 
1) Mengetahui hingga manakah siswa mencapai kemajuan kearah tujuan yang telah ditentukan.

2) Melalui efektivitas kurikulum.

3) Menentukan faktor biaya, waktu dan tingkat keberhasilan kurikulum.

Sering kita lihat bahwa kurikulum dirombak tanpa evaluasi yang sistematis. Jika evaluasi diadakan secara terus-menerus mungkin tak perlu kurikulum diganti seluruhnya, akan tetapi dapat senantiasa di perbaiki dan disempurnakan serta disesuaikan dengan perkembangan zaman.

b. Desain Evaluasi

Desain evaluasi menguraikan tentang (1) Data yang harus dikumpulkan, (2) analisis data untuk "membuktikan" nilai dan efektivitas kurikulum.

\section{PERAN GURU DALAM} ADMINISTRASI KURIKULUM

Di dalam pelaksanaan kurikulum tugas guru adalah mengkaji kurikulum tersebut melalui kegiatan perseorangan atau kelompok, dengan demikian guru dan kepala sekolah memahami kurikulum tersebut sebelum dilaksanakan. Dalam proses pengembangan kurikulum peran guru lebih banyak dalam tataran kelas. mencatat peran guru sebagai:

\section{Implementers}

Guru berperan untuk mengaplikasikan kurikulum yang sudah ada. Dalam melaksanakan perannya guru hanya menerima kebijakan perumus kurikulum. Guru tidak memiliki ruang baik untuk menentukan isi kurikulum maupun menentukan target kurikulum. Pada fase implementator kurikulum, peran guru dalam pengembangan kurikulum sebatas hanya menjalankan kurikulum yang telah disusun (sebelum reformasi pendidikan).

\section{Adapters}

Guru berperan lebih dari sebagai pelaksana kurikulum, akan tetapi juga sebagai penyelaras kurikulum dengan karakteristik dan kebutuhan siswa dan kebutuhan daerah. Dalam fase ini guru memberikan kewenangan untuk menyelesaikan kurikulum yang sudah ada dengan karakteristik sekolah dan kebutuhan lokal.

\section{Developers}

Guru berwewenang dalam mendesain kurikulum. Guru bukan saja dapat menentukan tujuan dan isi pelajaran yang akan disampaikan, akan tetapi juga dapat menentukan strategi apa yang harus dikembangkan serta bagaimana mengukur keberhasilannya. Sebagai pengembang kurikulum sepenuhnya guru dapat menyusun kurikulum sesuai dengan karakteristik, visi 
dan misi sekolah, serta sesuai dengan pengalaman belajar yang dibutuhkan siswa.

4. Researchers

Peran guru sebagai peneliti kurikulum. Peran ini dilaksanakan sebagai bagian dari tugas profesional guru yang memiliki tanggung jawab dalam meningkatkan kinerjanya sebagai guru. Dalam pelaksanakan peran sebagai peneliti, guru memiliki tanggung jawab untuk menguji berbagai komponen kurikulum.

Senada dengan itu, guru memegang peranan yang sangat penting dalam pengembangan kurikulum, sebagai berikut:

1. Pengelolaan administratif

2. Pengelolaan konseling dan pengembangan kurikulum

3. Guru sebagai tenaga profesi kependidikan

4. Berpartisipasi dalam pengembangan kurikulum

5. Meningkatkan keberhasilan sistem instruksional

6. Pendekatan kurikulum

7. Meningkatkan pemahaman konsep diri

8. Memupuk hubungan timbal balik yang harmonis dengan siswa 